\title{
COVID-Inconfidentes: How did COVID-19 and home office influence the prevalence of leisure-time physical inactivity? An analysis of before and during the pandemic
}

Samara Silva de Moura1, ${ }^{2}$ ( $\nabla$ samara.moura@aluno.ufop.edu.br)

Federal University of Ouro Preto

Luiz Antônio Alves Menezes-Júnior',2

Federal University of Ouro Preto

Ana Maria Sampaio Rocha ${ }^{2}$

Federal University of Ouro Preto

Luciano Garcia Lourenção

Federal University of Ouro Preto

Júlia Cristina Cardoso Carraro' ${ }^{1}$

Federal University of Ouro Preto

George Luiz Lins Machado-Coelho', ${ }^{2}$

Federal University of Ouro Preto

Adriana Lúcia Meireles ${ }^{2}$

Federal University of Ouro Preto

\section{Research Article}

Keywords: physical inactivity, COVID-19, social isolation, health research

Posted Date: November 10th, 2021

DOI: https://doi.org/10.21203/rs.3.rs-1016191/v1

License: (c) (i) This work is licensed under a Creative Commons Attribution 4.0 International License.

Read Full License 


\section{Abstract \\ Background}

The COVID-19 pandemic has brought drastic changes to the lives of the global population. The restrictions imposed by government agencies impacted the daily lives of citizens, influencing several health behaviors, such as physical activity (PA). Thus, the present study aimed to assess the prevalence of physical inactivity (PI) and its associated factors before and during the COVID-19 pandemic.

\section{Methods}

A population-based household seroepidemiological survey was conducted in two Brazilian municipalities located in the state of Minas Gerais, in which 1750 volunteers were interviewed between October and December 2020. Face-to-face interviews were conducted using a structured questionnaire in an electronic format. The moments considered for the PI analysis were M0 (before the pandemic), M1 (from March to July 2020), and M2 (from October to December 2020). Descriptive statistics and univariate and multivariate logistic regression were used to examine the factors associated with PI before (M0) and during the pandemic (M1 and M2).

\section{Results}

The prevalence of PI was higher in the first months of the pandemic (M1) (67.3\%; $95 \%$ confidence interval (Cl): 62.4-71.9) than in the months from October to December 2020 (M2) (58.7\%; 95\% Cl: 52.8-64.3); however, at both times (M1 and M2), PI was more prevalent than in the period before the pandemic started (M0) (39.7\%; 95\% Cl: 35.6-43.8). Individuals who were overweight, obese, and had low educational levels were more likely to be physically inactive. At both $\mathrm{M} 1$ and $\mathrm{M} 2$, individuals who worked at a home office were less likely to have PI.

\section{Conclusions}

The results suggest that the COVID-19 pandemic negatively influenced PA, substantially increasing the prevalence of PI. The determinants associated with PI were education, body mass index, and home office work.

\section{Background}

Severe acute respiratory syndrome coronavirus 2 (SARS-CoV-2), the causative agent of COVID-19, is part of a group of viruses responsible for causing acute respiratory syndrome. Infection caused by this virus has a clinical spectrum, ranging from asymptomatic to severe, and is associated with significant morbidity and mortality rates [1]. Due to the speed of spread of the virus and the high rate of infection, 
concomitant with the lack of knowledge of specific therapies, strategies have been established to mitigate the spread of the virus and reduce its impact [2]. Thus, one of the main prevention measures recommended by the World Health Organization (WHO) and adopted by governments is social restriction $[3,4]$, aimed at minimizing the exponential growth of infected people, avoiding deaths, and not generating a collapse of health systems [2].

Despite the benefits related to the decrease in viral circulation, social restriction promoted a sudden and drastic impact, both in the economy, with a reduction in household income, and in aspects related to health, such as eating habits, sleep quality, sedentary behavior, and physical activity (PA) practice [5]. Specifically, regarding PA practice, in the first months of the COVID-19 pandemic, the closure of several commercial establishments, such as gyms, and of public spaces open for PA practice, such as squares and parks, may have led to an increase in the prevalence of physical inactivity $(\mathrm{PI})$ in the population. According to the current recommendations ( $\geq 150 \mathrm{~min}$ of moderate PA or $\geq 75 \mathrm{~min}$ of vigorous activity), PI refers to the performance of insufficient amounts of moderate to vigorous intensity activities $[6,7]$ and may generate a negative impact on physical and mental health [8] and favor an increase in the prevalence of chronic diseases, such as coronary heart disease, colon and breast cancer, hypertension, stroke, type 2 diabetes, and osteoporosis $[9,10]$.

Thus, in the face of this critical and unprecedented scenario, a better understanding of how the COVID-19 pandemic influenced the population's PA practice becomes essential to produce important information for decision-making aimed at promoting quality of life and health of the population. Therefore, this study aimed to assess the prevalence of PI and its associated factors before and during the COVID-19 pandemic.

\section{Methods}

\section{Design and sample}

The COVID-Inconfidentes study is a population-based seroepidemiological household survey conducted between the months of October and December 2020 in two Brazilian municipalities (Ouro Preto and Mariana), located in the state of Minas Gerais, in the Iron Quadrangle region, which is an area with one of the largest iron ore reserves in the world and is economically important. Face-to-face interviews were conducted, using a structured questionnaire in an electronic format [11].

The sample size calculation considered the 2010 population estimate for the urban area of the municipal headquarters of each municipality, $95 \%$ confidence level, estimated infection by SARS-CoV-2 from 3$10 \%$, design effect equal to 1.5 , and $20 \%$ of recomposition, considering losses due to refusals, absence of the resident drawn, and the existence of closed households during the visit. The sample was calculated using the OpenEpi program (https://www.openepi.com/Menu/OE_Menu.htm), totaling 732 interviews for each municipality. We used conglomerate sampling in three stages: census sector (selected with 
probability proportional to the number of households), household (selected from a systematic sampling), and resident (randomly selected through the application Sorteador de Nomes ${ }^{\circledR}$ ) [11].

The sample weight of each selected unit (census sector, household, and individual) was calculated to correlate with the 2019 population projections (DATASUS) [12]. Adjustments were applied in this calculation to compensate for interview losses due to non-response. Further details on the sample calculation and field logistics are described by Meireles et al. [11].

\section{Outcome Variable: Leisure-time Physical Inactivity}

Outcome variable: Leisure-time physical inactivity

Participants were asked about PA during leisure time at different times related to the pandemic. For the moment before the pandemic (Moment 0 [M0]), we asked, "Before the pandemic (March/2020) did you practice physical exercise? (1) No; (2) Yes." Then, they were asked about the moment referring to the first months of the pandemic, referred to as Moment 1 (M1), "During the first months of the pandemic (March to July/2020), did you participate in physical exercise? (1) No; (2) Yes." Finally, they were asked about the moment of data collection, referred to as Moment 2 (M2), "Do you currently (October-December 2020) participate in any type of physical exercise? (1) No; (2) Yes."

Individuals who self-reported participating in PA during leisure time were classified as physically active, and those who said they did not participate in PA during leisure time were classified as physically inactive.

\section{Explanatory Variables}

We considered socioeconomic, anthropometric, and COVID-19-related variables as explanatory variables. The socioeconomic information analyzed were as follows: gender, age group (18-34 years; 35-59 years; $\geq$ 60 years), race (white; non-white), marital status (widowed, divorced, and single were categorized as single; married/stable union categorized as married), current income ( $\leq 2$ minimum wages; $>2$ to $\leq 4$ minimum wages; $>4$ minimum wages), and level of education ( $<9$ years of study; $\geq 9$ years of study).

The anthropometric profile was assessed by body mass index (BMI), calculated from self-reported weight and height. Adult individuals were classified according to criteria established by the WHO into: underweight (BMI $<18.5 \mathrm{~kg} / \mathrm{m}^{2}$ ); eutrophic (BMI 18.5-24.9 kg/m²), overweight (BMI $\geq 25 \mathrm{~kg} / \mathrm{m}^{2}<30$ $\left.\mathrm{kg} / \mathrm{m}^{2}\right)$ and obesity $\left(\mathrm{BMI} \geq 30 \mathrm{~kg} / \mathrm{m}^{2}\right)[13,14]$. For elderly people, the cut-off points used were underweight $\left(\mathrm{BMI}<22 \mathrm{~kg} / \mathrm{m}^{2}\right)$, eutrophic $\left(\mathrm{BMI} \geq 22\right.$ and $\left.<27 \mathrm{~kg} / \mathrm{m}^{2}\right)$, and overweight $\left(\geq 27 \mathrm{~kg} / \mathrm{m}^{2}\right)$ [15].

Regarding COVID-19, the following variables were included: work format during the pandemic, social withdrawal, COVID-19 symptomatology, and anti-SARS-CoV-2 serological examination. 
The questions related to the way of working were, "Currently, how is your work routine regarding location? (1) All work activities are being performed at my home (home office); (2) Part of the activities are performed in the traditional work environment, i.e., some days at home and others at the workplace; (3) All work activities are being performed in my work environment." This was categorized as normal routine (all activities at the workplace), home office (partial and/or total home office work), and no work (individuals who were not working during the pandemic).

Questions related to the COVID-19 pandemic were also evaluated, such as presenting at least one symptom in the last 15 days (fever, feeling feverish, palpitation, diarrhea, sore throat, cough, difficulty breathing, vomiting, skin rashes, unusual tiredness, ageusia, and anosmia). Responses were categorized into the presence (one or more symptoms) and absence of symptoms.

Social withdrawal was assessed using the question, "Are you currently socially withdrawn? (1) No; (2) Yes."

Finally, for seroepidemiological evaluation of anti-SARS-CoV-2 antibodies, serum samples were obtained by venipuncture using a $7.5 \mathrm{~mL}$ S-Monovette ${ }^{\circledR}$ (Sarstedt) serum gel tube. The samples diagnosed by qualitative immunochromatographic method using the One Step COVID 2019® test (Guangzhou Wondfo Biotech, China), according to the manufacturer's protocol. The seropositive results for this method are defined by the presence of two bands indicating, respectively, its performance and the non-differentiated presence of IgM/lgG anti-SARS-COV-2 antibodies [11].

\section{Ethical Declarations}

This study was approved by the Research Ethics Committee of the Universidade Federal de Ouro Preto, under protocol number 32815620.0.1001.5149. All procedures adopted in this study followed the Declaration of Helsinki and the Brazilian guidelines and norms for research involving humans.

\section{Data analysis}

The statistical analyses considered the complex sample design using the svy command of Stata ${ }^{\circledR}$ software, version 15.0. Descriptive analysis was performed, with calculation of frequency and $95 \%$ confidence interval $(95 \% \mathrm{Cl})$ for all variables of interest. McNemar's paired test was used to verify the change in the prevalence of PI during the three evaluations. Pearson's $\chi 2$ test was used to assess the possible relationship between home office and sociodemographic factors.

Univariate logistic regression was performed to assess the factors associated with PI before the pandemic and at the two time points of the COVID-19 pandemic. Based on the results of this analysis, variables with $p \leq 0.20$ were included in the multivariate logistic regression. A stepwise backward approach was used to choose the final model, and variables with $p \leq 0.05$, were retained. The odds ratios (ORs) and 95\% Cls were calculated. 
It is noteworthy that the variables income and education showed high collinearity in this study, so we chose education, instead of income, in the multivariate model.

\section{Results}

The survey included 1750 individuals, with the majority being female (52.4\%; 95\% Cl: 40.5-54.8), aged 3559 years (45.8\%; $95 \% \mathrm{Cl}: 41.2-50.5)$, non-white skin color $(73.9 \%$; $95 \% \mathrm{Cl}: 68.4-78.8)$, with less than nine years of schooling (69.1\%; $95 \% \mathrm{Cl}$ : $64.3-73.6)$, income below two minimum wages (41.2\%; $95 \%$ Cl: $35.6-$ 47.1), and eutrophic (41.1\%; 95\% Cl: 34.9-47.7). Most self-reported being in social restriction (86.2\%; $95 \%$ Cl: 82.0-89.5), had no symptoms of COVID-19 (70.6\%; 95\% Cl: 65.4-75.3), and were seronegative for the COVID-19 test (94.3\%; 95\% Cl: 92.3-95.8), according to Table 1. 
Table 1

General sociodemographic characteristics of the study sample. COVID-Inconfidentes, 2020.

\begin{tabular}{|ll|}
\hline Variables & $\%(95 \% \mathrm{Cl})$ \\
\hline Sex & \\
\hline Male & $47.6(40.5-54.8)$ \\
\hline Female & $52.4(45.2-59.4)$ \\
\hline Age group & \\
\hline 35-34 years & $35.1(30.8-39.7)$ \\
\hline$\geq 60$ years & $45.8(41.2-50.5)$ \\
\hline Declared Skin color & $19.1(15.7-23.0)$ \\
\hline White & \\
\hline Not white & $26.1(21.2-31.6)$ \\
\hline Education & $73.9(68.4-78.8)$ \\
\hline$<9$ years & \\
\hline Up to 9 years & $69.1(64.3-73.6)$ \\
\hline Family Income & $30.9(26.4-35.7)$ \\
\hline$\leq 2 M W$ & \\
\hline$>2$ a $\leq 4$ MW & $41.2(35.6-47.1)$ \\
\hline$>4 M W$ & $31.4(26.3-36.9)$ \\
\hline BMl & $27.4(22.3-33.1)$ \\
\hline Low weight & \\
\hline Eutrofic & $2.3(1.5-3.5)$ \\
\hline Overweight & $19.6(10.5(34.9-47.7)$ \\
\hline Obesity & \\
\hline Social Restriction & \\
\hline No & \\
\hline Yes & \\
\hline
\end{tabular}

Minimum wage; $\mathrm{Cl}$ : confidence intervals (95\%) 


\begin{tabular}{|lr|}
\hline Variables & $\%(95 \% \mathrm{Cl})$ \\
\hline Symptomatology COVID-19 & \\
\hline Absence of symptoms & $70.6(65.4-75.3)$ \\
\hline Presence of symptoms & $29.4(24.6-34.5)$ \\
\hline COVID-19 Test & \\
\hline Soronegative & $94.3(92.3-95.8)$ \\
\hline Soropositive & $5.7(4.2-7.6)$ \\
\hline Working status during the quarantine \\
\hline Normal routine & $32.0(27.5-36.9)$ \\
\hline No work & $47.843 .4-52.3)$ \\
\hline Home office & $20.2(16 .-26.8)$ \\
\hline Minimum wage; Cl: confidence intervals (95\%) \\
\hline
\end{tabular}

Figure 1 shows the prevalence of $\mathrm{PI}$ according to the time points investigated. We observed that $39.7 \%$ (95\% Cl: 35.6-43.8) of the individuals were inactive before the pandemic (M0). There was a $69.5 \%$ increase in the prevalence of PI at M1 (67.3\%; $95 \% \mathrm{Cl}$ : $62.4-71.9)$ and a $47.8 \%$ increase at M2 $(58.7 \% ; 95 \%$ $\mathrm{Cl}$ : 52.8-64.3) compared to that during the period before the pandemic $(\mathrm{M} 0)(\mathrm{p}<0.001)$. When we evaluated the moments M1 and M2, we observed that the prevalence of PI was $21.7 \%$ higher in M1 than in $\mathrm{M} 2(\mathrm{p}<0.001)$.

In Table 2, we observe the prevalence of PI according to the moments investigated and the crude OR of the explanatory variables and PI. No associations were observed between $\mathrm{PI}$ and the variables gender and related to COVID-19 (social withdrawal, symptomatology, and testing positive for COVID-19). On the other hand, age, education level, income, and BMI were associated with PI at different time points. It is noteworthy that self-reported skin color and marital status variables were associated only with M2. Furthermore, working at a home office was associated with PI at M1 and M2. 
Table 2

Univariate analysis of factors associated with physical inactivity: before and during two moments of the pandemic

\begin{tabular}{|c|c|c|c|c|c|c|}
\hline & $\begin{array}{l}\text { PI (M0) } \\
\text { (Before } \\
\text { March 2020) }\end{array}$ & $\begin{array}{l}P \\
\text { value }\end{array}$ & $\begin{array}{l}\text { PI (M1) } \\
\text { (March to } \\
\text { August 2020) }\end{array}$ & $\begin{array}{l}P \\
\text { value }\end{array}$ & $\begin{array}{l}\text { PI (M2) } \\
\text { (October to } \\
\text { December 2020) }\end{array}$ & $P$ value \\
\hline Variables & OR $(95 \% \mathrm{Cl})$ & & OR $(95 \% \mathrm{Cl})$ & & OR $(95 \% \mathrm{Cl})$ & \\
\hline \multicolumn{7}{|c|}{ SOCIODEMOGRAPHIC } \\
\hline \multicolumn{7}{|l|}{ Sex } \\
\hline Male & 1.00 & & 1.00 & & 1.00 & \\
\hline Female & $\begin{array}{l}1.27(0.87- \\
1.85)\end{array}$ & 0.210 & $\begin{array}{l}1.45(0.93- \\
2.26)\end{array}$ & 0.093 & $1.25(0.77-2.04)$ & 0.349 \\
\hline \multicolumn{7}{|l|}{ Age group } \\
\hline $18-34$ years & 1.00 & & 1.00 & & 1.00 & \\
\hline $35-59$ years & $\begin{array}{l}1.53(0.79- \\
2.98)\end{array}$ & 0.198 & $\begin{array}{l}1.58(1.01- \\
2.47)\end{array}$ & 0.044 & $1.67(1.08-2.58)$ & 0.021 \\
\hline$\geq 60$ years & $\begin{array}{l}1.83(1.05- \\
3.20)\end{array}$ & 0.033 & $\begin{array}{l}1.77(0.96- \\
3.26)\end{array}$ & 0.066 & $3.09(1.47-6.52)$ & 0.003 \\
\hline \multicolumn{7}{|c|}{ Skin color declared } \\
\hline White & 1.00 & & 1.00 & & 1.00 & \\
\hline Not white & $\begin{array}{l}1.45(0.95- \\
2.25)\end{array}$ & 0.084 & $\begin{array}{l}1.34(0.78- \\
2.30)\end{array}$ & 0.283 & $1.78(1.13-2.80)$ & 0.012 \\
\hline \multicolumn{7}{|c|}{ Marital Status } \\
\hline Married & 1.00 & & 1.00 & & 1.00 & \\
\hline Not-married & $\begin{array}{l}0.92(0.63- \\
1.35)\end{array}$ & 0.690 & $\begin{array}{l}0.74(0.40- \\
1.35)\end{array}$ & 0.335 & $0.55(0.33-0.90)$ & 0.019 \\
\hline \multicolumn{7}{|l|}{ Education } \\
\hline$\geq 9$ years & 1.00 & & 1.00 & & 1.00 & \\
\hline$<9$ years & $\begin{array}{l}2.53(1.49- \\
4.28)\end{array}$ & 0.001 & $\begin{array}{l}2.38(1.45- \\
3.93)\end{array}$ & 0.001 & $2.88(1.88-4.43)$ & $<0.0001$ \\
\hline \multicolumn{7}{|c|}{ Family Income } \\
\hline$\leq 2 \mathrm{MW}$ & 1.00 & & 1.00 & & 1.00 & \\
\hline
\end{tabular}

PI: physical inactivity; OR: Odds ratios; Cl: confidence intervals (95\%); MW: Minimum wage 


\begin{tabular}{|c|c|c|c|c|c|c|}
\hline & $\begin{array}{l}\text { PI (M0) } \\
\text { (Before } \\
\text { March 2020) }\end{array}$ & $\begin{array}{l}P \\
\text { value }\end{array}$ & $\begin{array}{l}\text { PI (M1) } \\
\text { (March to } \\
\text { August 2020) }\end{array}$ & $\begin{array}{l}P \\
\text { value }\end{array}$ & $\begin{array}{l}\text { PI (M2) } \\
\text { (October to } \\
\text { December 2020) }\end{array}$ & $P$ value \\
\hline Variables & OR (95\% Cl) & & OR $(95 \% \mathrm{Cl})$ & & OR $(95 \% \mathrm{Cl})$ & \\
\hline$>2 \mathrm{a} \leq 4 \mathrm{MW}$ & $\begin{array}{l}0.58(0.34- \\
0.96)\end{array}$ & 0.036 & $\begin{array}{l}0.60(0.35- \\
1.05)\end{array}$ & 0.078 & $0.76(0.42-1.39)$ & 0.377 \\
\hline$>4 \mathrm{MW}$ & $\begin{array}{l}0.26(0.13- \\
0.50)\end{array}$ & $\begin{array}{l}<.001 \\
0.01\end{array}$ & $\begin{array}{l}0.56(0.33- \\
0.95)\end{array}$ & 0.034 & $0.47(0.28-0.78)$ & 0.004 \\
\hline \multicolumn{7}{|c|}{ ANTHROPOMETRIC } \\
\hline \multicolumn{7}{|l|}{ BMC } \\
\hline Eutrofic & 1.00 & & 1.00 & & 1.00 & \\
\hline Low weight & $\begin{array}{l}1.26(0.48- \\
3.30)\end{array}$ & 0.639 & $\begin{array}{l}1.06(0.39- \\
2.91)\end{array}$ & 0.905 & $0.86(0.31-2.36)$ & 0.762 \\
\hline Overweight & $\begin{array}{l}1.79(1.10- \\
2.90)\end{array}$ & 0.019 & $\begin{array}{l}2.28(1.22- \\
4.23)\end{array}$ & $\langle .001$ & $2.08(1.19-3.61)$ & 0.010 \\
\hline Obesity & $\begin{array}{l}1.51(0.85- \\
2.67)\end{array}$ & 0.154 & $\begin{array}{l}2.57(1.53- \\
4.32)\end{array}$ & 0.011 & $2.15(1.25-3.74)$ & 0.007 \\
\hline \multicolumn{7}{|c|}{ VARIABLES COVID-19 } \\
\hline \multicolumn{7}{|c|}{ Working status during the quarantine } \\
\hline Normal routine & & & 1.00 & & 1.00 & \\
\hline No work & - & - & $\begin{array}{l}1.71(0.73- \\
1.86)\end{array}$ & 0.500 & $1.64(1.07-2.51)$ & 0.021 \\
\hline Home office & & & $\begin{array}{l}0.45(0.24- \\
0.85)\end{array}$ & 0.014 & $0.51(0.29-0.88)$ & 0.016 \\
\hline \multicolumn{7}{|c|}{ Social Restriction } \\
\hline No & - & - & 1.00 & & 1.00 & \\
\hline Yes & & & $\begin{array}{l}0.98(0.55- \\
1.75)\end{array}$ & 0.954 & $1.30(0.84-2.00)$ & 0.223 \\
\hline \multicolumn{7}{|c|}{ Symptomatology COVID-19 } \\
\hline $\begin{array}{l}\text { Absence of } \\
\text { symptoms }\end{array}$ & - & - & 1.00 & & 1.00 & \\
\hline $\begin{array}{l}\text { Presence of } \\
\text { symptoms }\end{array}$ & & & $\begin{array}{l}0.82(0.51- \\
1.34)\end{array}$ & 0.445 & $0.89(0.55-1.46)$ & 0.664 \\
\hline \multicolumn{7}{|l|}{ COVID-19 Test } \\
\hline Pl: physical in & y; OR: Odd & $\mathrm{s} ; \mathrm{Cl}$ & dence int $€$ & $5 \%$ & : Minimum wâ & \\
\hline
\end{tabular}




\begin{tabular}{|c|c|c|c|c|c|c|}
\hline & $\begin{array}{l}\text { PI (M0) } \\
\text { (Before } \\
\text { March 2020) }\end{array}$ & $\begin{array}{l}P \\
\text { value }\end{array}$ & $\begin{array}{l}\text { PI (M1) } \\
\text { (March to } \\
\text { August 2020) }\end{array}$ & $\begin{array}{l}\mathrm{P} \\
\text { value }\end{array}$ & $\begin{array}{l}\text { PI (M2) } \\
\text { (October to } \\
\text { December 2020) }\end{array}$ & $P$ value \\
\hline Variables & OR (95\% Cl) & & OR $(95 \% \mathrm{Cl})$ & & OR $(95 \% \mathrm{Cl})$ & \\
\hline Soronegative & - & - & 1.00 & & 1.00 & \\
\hline Soropositive & & & $\begin{array}{l}0.73(0.35- \\
1.52)\end{array}$ & 0.404 & $1.18(0.60-2.32)$ & 0.611 \\
\hline
\end{tabular}

The final models for each time point are listed in Table 3. Individuals with up to 9 years of schooling were twice as likely to be physically inactive at the three time points evaluated (M0: OR=2.55; 95\% Cl: 1.41 4.60; $\mathrm{M} 1$ : OR=1.83; 95\% Cl: 1.11-3.03; M2: OR=1.78; 95\% Cl: 1.04-3.04). Regarding nutritional status, we found that overweight individuals were $79-150 \%$ more likely to be physically inactive at the three time points evaluated (M0: OR=1.79; $95 \% \mathrm{Cl}$ : 1.38-2.81; $\mathrm{M} 1$ : $\mathrm{OR}=2.50 ; 95 \% \mathrm{Cl}: 1.40-4.46 ; \mathrm{M} 2$ : $\mathrm{OR}=2.19 ; 95 \% \mathrm{Cl}$ : 1.30-3.67). Those with obesity were $85-124 \%$ more likely to be physically inactive (M1: OR=2.24; $95 \% \mathrm{Cl}$ : 1.34-3.75; $\mathrm{M} 2$ : OR=1.85; $95 \% \mathrm{Cl}: 1.15-3.00)$. Regarding work status during the pandemic, individuals working at a home office were $92-104 \%$ less likely to be physically inactive (M1: OR=0.52; $95 \%$ Cl: 0.30 0.89; $\mathrm{M} 2$ : OR=0.49; $95 \% \mathrm{Cl}: 0.28-0.84)$. 
Table 3

Association of physical inactivity before and during two moments of the COVID-19 pandemic
$\mathrm{PI}(\mathrm{M} 0)$
PI (M1)
PI (M2)

(Before March 2020)

(March to August 2020)

(October to December 2020)

OR $(95 \% \mathrm{Cl})$

$\mathrm{p}$

OR $(95 \% \mathrm{Cl})$

OR (95\% Cl)

p

\section{Education}

\begin{tabular}{|c|c|c|c|c|c|c|}
\hline$\leq 9$ years & 1.00 (Ref) & & 1.00 (Ref) & & 1.00 (Ref) & \\
\hline$>9$ year & $\begin{array}{l}2.55(1.41- \\
4.60)\end{array}$ & 0.002 & $\begin{array}{l}1.83(1.11- \\
3.03)\end{array}$ & 0.018 & $1.78(1.04-3.04)$ & 0.035 \\
\hline
\end{tabular}

BMC

\begin{tabular}{|c|c|c|c|c|c|c|}
\hline Eutrofic & 1.00 (Ref) & & 1.00(Ref) & & 1(Ref) & \\
\hline Low wieght & $\begin{array}{l}0.96(0.35- \\
2.66)\end{array}$ & 0.943 & $\begin{array}{l}0.64(0.23- \\
1.78)\end{array}$ & 0.382 & $0.62(0.22-1.76)$ & 0.364 \\
\hline Overweight & $\begin{array}{l}1.79(1.38- \\
2.81)\end{array}$ & 0.012 & $\begin{array}{l}2.50(1.40- \\
4.46)\end{array}$ & 0.002 & $2.19(1.30-3.67)$ & 0.003 \\
\hline Obesity & $\begin{array}{l}1.19(0.70- \\
2.05)\end{array}$ & 0.516 & $\begin{array}{l}2.24(1.34- \\
3.75)\end{array}$ & 0.003 & $1.85(1.15-3.00)$ & 0.012 \\
\hline
\end{tabular}

Working status during the quarantine

Normal

routine

1.00 (Ref) $\quad 1.00$ (Ref)

No work

$1.29(0.77-$
$2.20)$

0.325

$0.97(0.62-1.51)$

0.880

Home office

$0.52(0.30-$
$0.89)$

0.019

$0.49(0.28-0.84)$

0.010

PI: physical inactivity; OR: Odds ratios; Cl: confidence intervals (95\%). Multivariate model fitted to the best fit model by the stepwise backward technique, using those who reported practicing physical activity (PA) as the reference. All three models were adjusted for sex and age.

In Table 4, the participants who belonged to the group that worked at a home office were mostly female (54.3\%; 95\% Cl: 44.4-63.8; $p=0.001)$, aged between 35 and 59 years $(51.8 \% ; 95 \% \mathrm{Cl}: 42.9-60.5 ; p<0.001)$, non-white skin color $(64.1 \% ; 95 \% \mathrm{Cl}: 55.9-71.4 ; \mathrm{p}=0.02)$, underwent more than 9 years of schooling (95.4\%; 95\% Cl: 90.6-97.7; $p$ <0.001), had income above four minimum wages (51.6\%; 95\% Cl: 41.3-61.7; $p$ $<0.001)$, and self-reported as being in social restriction (88.0\%; $95 \% \mathrm{Cl}$ : 82.6-91.8; $\mathrm{p}<0.001)$. 
Table 4

Occupation categories: not working, normal work routine (i.e., at the workplace), and home office

\section{Variables}

No work

$47.8 \%$

(95\% Cl:43.3-52.3)
Normal routine

$32.0 \%$

(95\% Cl:27.5-36.9)
Home office

$20.2 \%$

(95\% Cl:16.2-24.7)
SOCIODEMOGRAPHIC

\section{Sex}

Male

Female

Age group

18-34 years

35-59 years

$\geq 60$ years

Skin color declared

White

Not white

\section{Marital Status}

Married

Not-married

Living status

Alone

Not-alone

Education

$>9$ anos

Up to 9 years

Family Income

$\leq 2 \mathrm{MW}$
$>2 \mathrm{a} \leq 4 \mathrm{MW}$
$>4 \mathrm{MW}$

$\leq 2 \mathrm{MW}$

Minimum wage; $\mathrm{Cl}$ : confidence intervals (95\%)

$38.5(29.8-48.1) \quad 62.3(51.6-71.9) \quad 45.7(36.1-55.5)$

$61.4(51.8-70.2) \quad 37.7(28.0-48.3) \quad 54.3(44.4-63.8)$

$<0.001$

\begin{tabular}{llll}
$24.2(18.9-30.3)$ & $46.3(35.4-57.5)$ & $43.4(34.1-53.1)$ & \\
\hline $40.3(32.4-48.7)$ & $50.2(39.7-60.6)$ & $51.8(42.9-60.5)$ & $<0.001$ \\
\hline $35.5(29.1-42.4)$ & $3.5(1.8-8.0)$ & $4.8(2.8-8.0)$ &
\end{tabular}

$21.2(16.8-26.5)$

$27.0(18.0-38.4)$

$35.9(28.5-44.0)$

$78.8(73.5-83.2) \quad 73.0(61.6-82.0)$

$64.1(55.9-71.4)$

0.025

$56.4(48.8-63.6)$

$51.1(40.2-61.8)$

$47.5(39.8-55.2)$

$43.6(36.3-51.1)$

$48.9(38.1-59.7)$

$52.5(44.8-60.1)$

0.293

p value 


\begin{tabular}{|c|c|c|c|c|}
\hline \multirow[t]{3}{*}{ Variables } & No work & Normal routine & Home office & $p$ value \\
\hline & $47.8 \%$ & $32.0 \%$ & $20.2 \%$ & \\
\hline & (95\% Cl:43.3-52.3) & (95\% Cl:27.5-36.9) & (95\% Cl:16.2-24.7) & \\
\hline \multicolumn{5}{|l|}{ VARIABLES COVID-19 } \\
\hline \multicolumn{5}{|c|}{ Symptomatology COVID-19 } \\
\hline Absence of symptoms & $68.5(62.1-74.2)$ & $76.9(68.0-83.9)$ & $65.8(57.1-73.5)$ & \\
\hline Presence of symptoms & $31.5(25.8-37.8)$ & $23.1(16.0-32.0)$ & $34.2(26.5-42.8)$ & 0.080 \\
\hline \multicolumn{5}{|l|}{ Social Restriction } \\
\hline No & $9.7(6.7-13.7)$ & $21.0(14.3-29.7)$ & $12.0(8.1-17.3)$ & \\
\hline Yes & $90.3(86.2-93.2)$ & $79.0(70.2-85.6)$ & $88.0(82.6-91.8)$ & $<0.001$ \\
\hline \multicolumn{5}{|l|}{ COVID-19 Test } \\
\hline Soronegative & $92.7(89.1-95.1)$ & $95.1(92.2-97.0)$ & $96.8(94.2-98.3)$ & \\
\hline Soropositive & $7.3(4.8-10.9)$ & $4.9(3.0-7.8)$ & $3.2(1.7-5.7)$ & 0.058 \\
\hline
\end{tabular}

\section{Discussion}

This study presents important evidence on PI during the COVID-19 pandemic, suggesting that social restriction, although necessary, may have contributed to a higher prevalence of $\mathrm{Pl}$ at the two time points assessed after the pandemic onset. The results revealed that before and during the pandemic, leisuretime PI was associated with lower educational attainment, overweight, and obesity. Moreover, working in a home office was a protective factor for PI in both moments evaluated during the pandemic.

PA practice benefits different aspects of life, whether physical, mental, and social [16]. However, the pandemic caused abrupt changes, which contributed to the increase in the prevalence of PI [17]. Several studies have already shown evidence of a PI pandemic, even before COVID-19 [18], leading the WHO to launch a global action plan to encourage PA practice in June 2018, seeking a 15\% reduction in PI rates by 2030 [19]. However, with the advent of the COVID-19 pandemic, there has been a worsening of this scenario due to social restriction and reduced urban mobility [17].

Our findings are corroborated by recent literature, which highlights the considerable increase in PI during the COVID-19 pandemic. The results further indicate that the rates of PI found in the study population during the pandemic are more than double the global prevalence (27.5\%), as well as is higher than the rate found in other countries during social restriction [20,21]. In China, a population-based study conducted in the early pandemic period (January and February 2020) with 12,107 participants found that $60 \%$ of the population did not meet the 150 min per week of PA in the four domains (leisure, commuting, 
home, and work) and were, therefore, considered physically inactive [20]. A similar condition was reported in Spain, in which self-reported PA in the four domains decreased significantly across the population during the lockdown, resulting in a reduction of $16.8 \%(p<0.001)$ and $58.2 \%(p<0.001)$ in vigorous PA and walking time, respectively [22]. Moreover, corroborating our results, an online survey conducted in Brazil between April and May 2020 with 43,995 adults found a prevalence of leisure-time PI of $66.6 \%$, with $21.3 \%$ of individuals becoming inactive after the onset of the pandemic [23].

It is important to highlight that PA is determined by several individual, social, environmental, and political factors [24], and, in general, it may vary according to age, gender, income, and education level [25]. In the present study, we found an association between leisure-time PI and lower educational level, overweight status, and obesity, which can be considered to hinder the participation of leisure-time PA [26, 27].

It is well documented that lower education is associated with PI in general. Our findings reinforce data from the literature in which low education was reported as a factor that increases the likelihood of PI [28]. In a study by Kari et al. [25], the authors stated that a higher level of education is related to making healthier lifestyle decisions, including PA. Similar findings were found in the study by Park and Kang [29], which showed that an increase in the years of schooling in adulthood induces individuals to participate in PA more regularly. Furthermore, a direct relationship is perceived between schooling and PA that may be permeated by income, which, in turn, offers more opportunities to invest in PA [25,30]. Furthermore, a peer-reviewed systematic review identified education as a positive determinant of PA [31].

The higher probability of occurrence of $\mathrm{Pl}$ in overweight or obese individuals found in our study is a relevant factor because, in addition to complicating the overweight condition, it may contribute to the emergence and worsening of chronic diseases [32]. Studies prior to the COVID-19 pandemic have stated that a higher level of PA is more prevalent in individuals with lower $\mathrm{BMI}$, and the reverse is also true, that is, subjects with higher BMI are less likely to meet the guidelines for moderate to vigorous PA [33-36]. Although the results of our study cannot demonstrate causal relationships, it is well-established in the literature that participating in PA prevents obesity and metabolic diseases arising from overweight status $[32,37,38]$. These findings are alarming and require the implementation of actions and public policies to encourage PA engagement, as the restrictions imposed to mitigate the circulation of SARS-CoV-2 contributed to weight gain in the population and, in the current scenario, the control of overweight status or obesity becomes more challenging. Moreover, the high prevalence of overweight status and obesity, along with reduction in PA practice during the pandemic, increases vulnerability to several diseases, including COVID-19, leading to increased costs and a possible crisis in the health care system [39, 40].

Remote work was an important change implemented in the routine of the population due to the COVID-19 pandemic, and home office work was identified as a protective factor for FI during the period of social restriction. To date, very few studies have aimed at understanding the health implications of home offices. Changes in physical behaviors, such as increased sitting and lying down time, and less time spent on PA were expected [41]. However, our study found an association between home office work as a protective factor for $\mathrm{PI}$. This is in contrast to the findings of a study recently conducted in Brazil, in which 
office workers were found to have reduced their PA practice in leisure time when comparing the periods before (office workday, September 2019) and during the pandemic (home office workday, July 2020), [41]. However, these results were contradictory. In a study conducted in Sweden that compared the days workers stayed at home vs. the days they commuted to the office, it was shown that physical behaviors during work and leisure did not change significantly. The authors suggested that individuals tend to work fewer hours when they perform their function at home, which may be an indication of additional time for $\mathrm{PA}$ in leisure time [42].

Additionally, a longitudinal study of 112 office workers in the United States, initiated in January 2018, immediately before (i.e., February 2020) and during the detachment of COVID-19 (i.e., at the time of survey data collection), recorded no significant changes in PA during leisure [43]. Another study by Martins et al. [44] observed a higher prevalence of PI among people who work than among those who did not work. This was due to the lack of time available for leisure, which is a common report regarding physical exercise or sports [44]. This may add to our findings as subjects in a home office were able to have a flexible schedule and, therefore, dedicate themselves to some PAs in their leisure time.

The abovementioned findings indicate that working at home can create opportunities for individuals to become physically active. It reduces the time spent commuting to work and/or school, in addition to reducing time spent on the workday, providing flexible schedules and additional time to engage in PA. This association is also influenced by the profile of individuals who worked at home offices, with a higher proportion having higher income and more education.

Finally, this study has some limitations. The outcome variable was evaluated only in a binary way if individuals engaged in PA during leisure time. Thus, we did not evaluate the frequency, duration, and type of PA modality, limiting the obtainment of information about the individuals' level of engagement, according to the world recommendations on PA. However, it is important to point out that, to the best of our knowledge, our study is one of the first investigations on PI at different times of the COVID-19 pandemic in Brazil. This outcome variable is among the top five risk factors for increased chronic disease occurrence and mortality worldwide, accounting for up to $10 \%$ of the global burden of coronary heart disease, type 2 diabetes, breast and colon cancer, and premature mortality [45]. Therefore, information about the impacts of the COVID-19 pandemic on PI is valuable and contributes to the planning and targeting of population health promotion actions. Therefore, it is important to understand the changes in PI during the period of restricted social movement, so that the negative effects can be reversed, from the creation and implementation of effective and feasible policies to increase PA at all population levels.

\section{Conclusions}

These results suggest that the disruption of daily routine due to the COVID-19 pandemic may have negatively influenced the practice of leisure-time PA, substantially increasing the prevalence of $\mathrm{Fl}$ in the first months of the pandemic (M1), a condition that remained at M2. We also found that during the 
COVID-19 pandemic, individuals with lower education, overweight status, and obesity were more likely to be physically inactive, and home office work favored PA.

\section{Abbreviations}

PA

physical activity

PI

physical inactivity

M0

(before the pandemic)

M1

(from March to July 2020)

M2

(from October to December 2020)

WHO

World Health Organization

SARS-CoV-2

severe acute respiratory syndrome coronavirus 2

$\mathrm{BMI}$

body mass index

OR

odds ratios

$\mathrm{Cl}$

confidence intervals (95\%)

MW

Minimum wage.

\section{Declarations}

\section{Ethics approval and consent to participate}

This study was approved by the Research Ethics Committee of the Universidade Federal de Ouro Preto, under protocol number 32815620.0.1001.5149. All procedures adopted in this study followed the Declaration of Helsinki and the Brazilian guidelines and norms for research involving humans.

\section{Consent for publication}

Informed consent was obtained from all individual participants included in the study.

\section{Availability of data and materials}


The datasets generated and/or analyzed as part of the current study are not publicly available due to confidentiality agreements with subjects. However, they can be made available solely for the purpose of review and not for the purpose of publication from the corresponding author upon reasonable request.

\section{Competing interests}

The authors declare that they have no competing interests.

\section{Funding}

Coordenação de Aperfeiçoamento de Pessoal de Nível Superior, Processo número 88881.504995/202001.

\section{Authors' contributions}

SSM participation the data collection, data interpretation, writing and revision of the manuscript, under the guidance of JCCC and ALM who assisted in each stage and finalization of the manuscript. LAAMJ assisted in the collection, interpretation of data and revision of the manuscript. GLLMC, AMSR and LGL assisted in the revision of the manuscript. The authors declare that there is no conflict of interest with the current publication, and all authors have approved the final version of the manuscript.

\section{Acknowledgments}

The authors thank the Federal University of Ouro Preto, the Municipal Health Secretaries of Ouro Preto, and Mariana. To the Nutrition and Public Health Research and Teaching Group of the Federal University of Ouro Preto and the Laboratory of Epidemiology at the Medical School of the Federal University of Ouro Preto.

\section{References}

1. Clerkin KJ, Fried JA, Raikhelkar J, Sayer G, Griffin JM, Masoumi A, Jain SS, Burkhoff D, Kumaraiah D, Rabbani L: COVID-19 and cardiovascular disease. Circulation 2020, 141(20):16481655. https://doi.org/10.1161/CIRCULATIONAHA.120.046941

2. Oliveira Neto L, Elsangedy HM, Tavares VDO, Teixeira CVLS, Behm DG, Silva-Grigoletto ME. \#TreineEmCasa - Treinamento físico em casa durante a pandemia do COVID-19 (SARS-CoV-2): abordagem fisiológica e comportamental. Rev Bras Fisiol Exerc 2020;19(2supl):S9S19.https://doi.org/10.33233/rbfe.v19i2.4006

3. Wilder-Smith A, Freedman DO: Isolation, quarantine, social distancing and community containment: pivotal role for old-style public health measures in the novel coronavirus (2019-nCoV) outbreak. Journal of travel medicine 2020. https://doi.org/10.1093/jtm/taaa020 
4. Gostin LO, Wiley LFJJ: Governmental public health powers during the COVID-19 pandemic: stay-athome orders, business closures, and travel restrictions. 2020, 323(21):2137-

2138. https://doi.org/10.1001/jama.2020.5460

5. Di Renzo L, Gualtieri P, Pivari F, Soldati L, Attinà A, Cinelli G, Leggeri C, Caparello G, Barrea L, Scerbo F: Eating habits and lifestyle changes during COVID-19 lockdown: an Italian survey. Journal of translational medicine 2020, 18:1-15. https://doi.org/10.1186/s12967-020-02399-5

6. Tremblay MS, Aubert S, Barnes JD, Saunders TJ, Carson V, Latimer-Cheung AE, Chastin SF, Altenburg TM, Chinapaw MJ: Sedentary behavior research network (SBRN)-terminology consensus project process and outcome. International journal of behavioral nutrition physical activity 2017, 14(1):117. https://doi.org/10.1186/s12966-017-0525-8

7. WHO: WHO guidelines on physical activity and sedentary behaviour. Geneva: World Health Organization. 2020. https://www.who.int/publications/i/item/9789240015128. (Accessed: 05 Oct 2021).

8. Pérez-Rodrigo C, Gianzo Citores M, Hervás Bárbara G, Ruiz-Litago F, Casis Sáenz L, Arija V, LópezSobaler AM, Martínez de Victoria E, Ortega RM, Partearroyo T: Patterns of change in dietary habits and physical activity during lockdown in Spain due to the COVID-19 pandemic. Nutrients 2021, 13(2):300. https://doi.org/10.3390/nu13020300

9. Moradi G, Mostafavi F, Piroozi B, Zareie B, Mahboobi M, Rasouli MA: The prevalence of physical inactivity in Iranian adolescents and the impact of economic and social inequalities on it: results of a National Study in 2018. BMC public health 2020, 20(1):1-9. https://doi.org/10.1186/s12889-020-09618-0

10. Humphreys BR, McLeod L, Ruseski JE: Physical activity and health outcomes: evidence from Canada. Health economics 2014, 23(1):33-54. https://doi.org/10.1002/hec.2900

11. Meireles AL, Lourenção LG, Menezes Júnior LAAd, Coletro HN, Justiniano ICS, Moura SSd, Diniz AP, Sabião; TdS, Rocha; AMS, Batista; AP et al: COVID-Inconfidentes - SARS-CoV-2 seroprevalence in twoBrazilian urban areas during the pandemic first wave: studyprotocol and initial results. SciELO Preprints 2021, 10.1590/SciELOPreprints.2720. https://doi.org/10.1590/SciELOPreprints.2720

12. Saúde BMdSPd: Informações de Saúde (TABNET)-Demográficas e Socioeconômicas. In.: o Ministério Brasília; 2010.

13. WHO: Obesity: preventing and managing the global epidemic: report of a WHO consultation on obesity, Geneva, 3-5 June 1997. In.: World Health Organization; 1998. https://apps.who.int/iris/handle/10665/42330 (Accessed: 12 Oct 2021).

14. Organização Pan-Americana de Saúde O: XXXVI Reunión del Comitê Asesor de Investigaciones en Salud-Encuesta Multicéntrica-SALUD BIENESTAR Y ENVEJECIMIENTO (SABE) EN AMÉRICA LATINA Y EL CARIBE. Inf Prelim 2001. https://iris.paho.org/handle/10665.2/45890 (Accessed: 12 Oct 2021). 
15. Lipschitz DA: Screening for nutritional status in the elderly. Primary Care: Clinics in Office Practice 1994, 21(1):55-67. https://doi.org/10.1016/S0095-4543(21)00452-8

16. Bann D, Scholes S, Fluharty M, Shure N: Adolescents' physical activity: cross-national comparisons of levels, distributions and disparities across 52 countries. International Journal of Behavioral Nutrition Physical Activity 2019, 16(1):1-11. https://doi.org/10.1186/s12966-019-0897-z

17. Ruíz-Roso MB, de Carvalho Padilha P, Matilla-Escalante DC, Brun P, Ulloa N, Acevedo-Correa D, Arantes Ferreira Peres W, Martorell M, Rangel Bousquet Carrilho T, de Oliveira Cardoso L: Changes of physical activity and ultra-processed food consumption in adolescents from different countries during Covid-19 pandemic: An observational study. Nutrients 2020,

12(8):2289. https://doi.org/10.3390/nu12082289

18. Kohl 3rd HW, Craig CL, Lambert EV, Inoue S, Alkandari JR, Leetongin G, Kahlmeier S: The pandemic of physical inactivity: global action for public health. The lancet 2012, 380(9838):294305. https://doi.org/10.1016/S0140-6736(12)60898-8

19. WHO: Global action plan on physical activity 2018-2030: more active people for a healthier world: World Health Organization; 2019. https://apps.who.int/iris/bitstream/handle/10665/272722/9789241514187-eng.pdf. (Accessed: 06 Oct 2021).

20. Qin F, Song Y, Nassis GP, Zhao L, Dong Y, Zhao C, Feng Y, Zhao J: Physical activity, screen time, and emotional well-being during the 2019 novel coronavirus outbreak in China. International journal of environmental research public health 2020, 17(14):5170. https://doi.org/10.3390/ijerph17145170

21. Guthold R, Stevens GA, Riley LM, Bull FC: Worldwide trends in insufficient physical activity from 2001 to 2016: a pooled analysis of 358 population-based surveys with 1. 9 million participants. The lancet global health 2018, 6(10):e1077-e1086. https://doi.org/10.1016/S2214-109X(18)30357-7

22. Castañeda-Babarro A, Arbillaga-Etxarri A, Gutiérrez-Santamaría B, Coca A: Physical activity change during COVID-19 confinement. International Journal of Environmental Research and Public Health 2020, 17(18):6878. https://doi.org/10.3390/ijerph17186878

23. Werneck AO, Silva DR, Malta DC, Souza-Júnior PR, Azevedo LO, Barros MB, Szwarcwald CL: Physical inactivity and elevated TV-viewing reported changes during the COVID-19 pandemic are associated with mental health: A survey with 43,995 Brazilian adults. Journal of Psychosomatic Research 2021, 140:110292. https://doi.org/10.1016/j.jpsychores.2020.110292

24. Bauman AE, Reis RS, Sallis JF, Wells JC, Loos RJ, Martin BW, Group LPASW: Correlates of physical activity: why are some people physically active and others not? The lancet 2012, 380(9838):258-

271. https://doi.org/10.1016/S0140-6736(12)60735-1 
25. Kari JT, Viinikainen J, Böckerman P, Tammelin TH, Pitkänen N, Lehtimäki T, Pahkala K, Hirvensalo M, Raitakari OT, Pehkonen J: Education leads to a more physically active lifestyle: Evidence based on Mendelian randomization. Scandinavian journal of medicine science in sports 2020, 30(7):11941204. https://doi.org/10.1111/sms.13653

26. Mielke GI, Hallal PC, Rodrigues GBA, Szwarcwald CL, Santos FV, Malta DC: Prática de atividade física e hábito de assistir à televisão entre adultos no Brasil: Pesquisa Nacional de Saúde 2013. Epidemiologia e Serviços de Saúde 2015, 24:277-286. https://doi.org/10.5123/S167949742015000200010

27. Crochemore-Silva I, Knuth AG, Wendt A, Nunes BP, Hallal PC, Santos LP, Harter J, Pellegrini DdCP: Physical activity during the COVID-19 pandemic: a population-based cross-sectional study in a city of South Brazil. Ciência Saúde Coletiva 2020, 25:4249-4258. https://doi.org/10.1590/1413812320202511.29072020

28. Biernat E, Piątkowska M: Sociodemographic determinants of physical inactivity of people aged 60 years and older: a cross-sectional study in Poland. BioMed research international 2020, 2020. https://doi.org/10.1155/2020/7469021

29. Park C, Kang C: Does education induce healthy lifestyle? Journal of health economics 2008, 27(6):1516-1531. https://doi.org/10.1016/j.jhealeco.2008.07.005

30. Meltzer DO, Jena AB: The economics of intense exercise. Journal of Health Economics 2010, 29(3):347-352. https://doi.org/10.1016/j.jhealeco.2010.03.005

31. Trost SG, Owen N, Bauman AE, Sallis JF, Brown W: Correlates of adults' participation in physical activity: review and update. Medicine science in sports exercise 2002, 34(12):19962001. https://doi.org/10.1097/00005768-200212000-00020

32. Guilherme FR, Molena-Fernandes CA, Guilherme VR, Fávero MTM, Reis EJBd, Rinaldi W: Inatividade física e medidas antropométricas em escolares de Paranavaí, Paraná, Brasil. Revista Paulista de Pediatria 2015, 33:50-55. https://doi.org/10.1016/j.rpped.2014.11.009

33. Tye LS, Scott T, Haszard JJ, Peddie MC: Physical activity, sedentary behaviour and sleep, and their association with BMI in a sample of adolescent females in New Zealand. International Journal of Environmental Research Public Health 2020, 17(17):6346. https://doi.org/10.3390/ijerph17176346

34. Huaidong Du, Derrick Bennett, Liming Li , Gary Whitlock, Yu Guo, Rory Collins, Junshi Chen , Zheng Bian , Lai-San Hong, Shixian Feng et al: Physical activity and sedentary leisure time and their associations with BMI, waist circumference, and percentage body fat in 0.5 million adults: the China Kadoorie Biobank study. The American journal of clinical nutrition 2013, 97(3):487-

496. https://doi.org/10.3945/ajcn.112.046854

Page 21/23 
35. Hill JO, Wyatt HR: Role of physical activity in preventing and treating obesity. Journal of applied physiology 2005. https://doi.org/10.1152/japplphysiol.00137.2005

36. Besson H, Ekelund U, Luan J, May A, Sharp S, Travier N, Agudo A, Slimani N, Rinaldi S, Jenab M: A cross-sectional analysis of physical activity and obesity indicators in European participants of the EPICPANACEA study. International journal of obesity 2009, 33(4):497-506. https://doi.org/10.1038/ijo.2009.25

37. Neto AS, Sasaki JE, Mascarenhas LP, Boguszewski MC, Bozza R, Ulbrich AZ, da Silva SG, de Campos W: Physical activity, cardiorespiratory fitness, and metabolic syndrome in adolescents: a crosssectional study. BMC Public Health 2011, 11(1):1-7. https://doi.org/10.1186/1471-2458-11-674

38. Hsu Y-W, Belcher BR, Ventura EE, Byrd-Williams CE, Weigensberg MJ, Davis JN, McClain AD, Goran MI, Spruijt-Metz D: Physical activity, sedentary behavior, and the metabolic syndrome in minority youth. Medicine science in sports exercise 2011, 43(12):2307. https://doi.org/10.1249/MSS.0b013e318222020f

39. López-Moreno M, López MTI, Miguel M, Garcés-Rimón M: Physical and psychological effects related to food habits and lifestyle changes derived from covid-19 home confinement in the Spanish population. Nutrients 2020, 12(11):3445. https://doi.org/10.3390/nu12113445

40. Sidor A, Rzymski P: Dietary choices and habits during COVID-19 lockdown: experience from Poland. Nutrients 2020, 12(6):1657. https://doi.org/10.3390/nu12061657

41. Brusaca LA, Barbieri DF, Mathiassen SE, Holtermann A, Oliveira AB: Physical Behaviours in Brazilian Office Workers Working from Home during the COVID-19 Pandemic, Compared to before the Pandemic: A Compositional Data Analysis. International Journal of Environmental Research Public Health 2021, 18(12):6278. . https://doi.org/10.3390/ijerph18126278

42. Hallman DM, Januario LB, Mathiassen SE, Heiden M, Svensson S, Bergström G: Working from home during the COVID-19 outbreak in Sweden: effects on 24-h time-use in office workers. BMC public health 2021, 21(1):1-10. https://doi.org/10.1186/s12889-021-10582-6

43. Barone Gibbs B, Kline C, Huber K, Paley J, Perera SJOM: COVID-19 shelter-at-home and work, lifestyle and well-being in desk workers. Occupational Medicine 2021, 71(2):86-

94. https://doi.org/10.1093/occmed/kqab011

44. Martins TG, Assis MAAd, Nahas MV, Gauche H, Moura ECJRdSP: Inatividade física no lazer de adultos e fatores associados. 2009, 43:814-824. https://doi.org/10.1590/S0034-89102009005000058

45. Lee I-M, Shiroma EJ, Lobelo F, Puska P, Blair SN, Katzmarzyk PT, Group LPASW: Effect of physical inactivity on major non-communicable diseases worldwide: an analysis of burden of disease and life expectancy. The lancet 2012, 380(9838):219-229. https://doi.org/10.1016/S0140-6736(12)61031-9

\section{Figures}




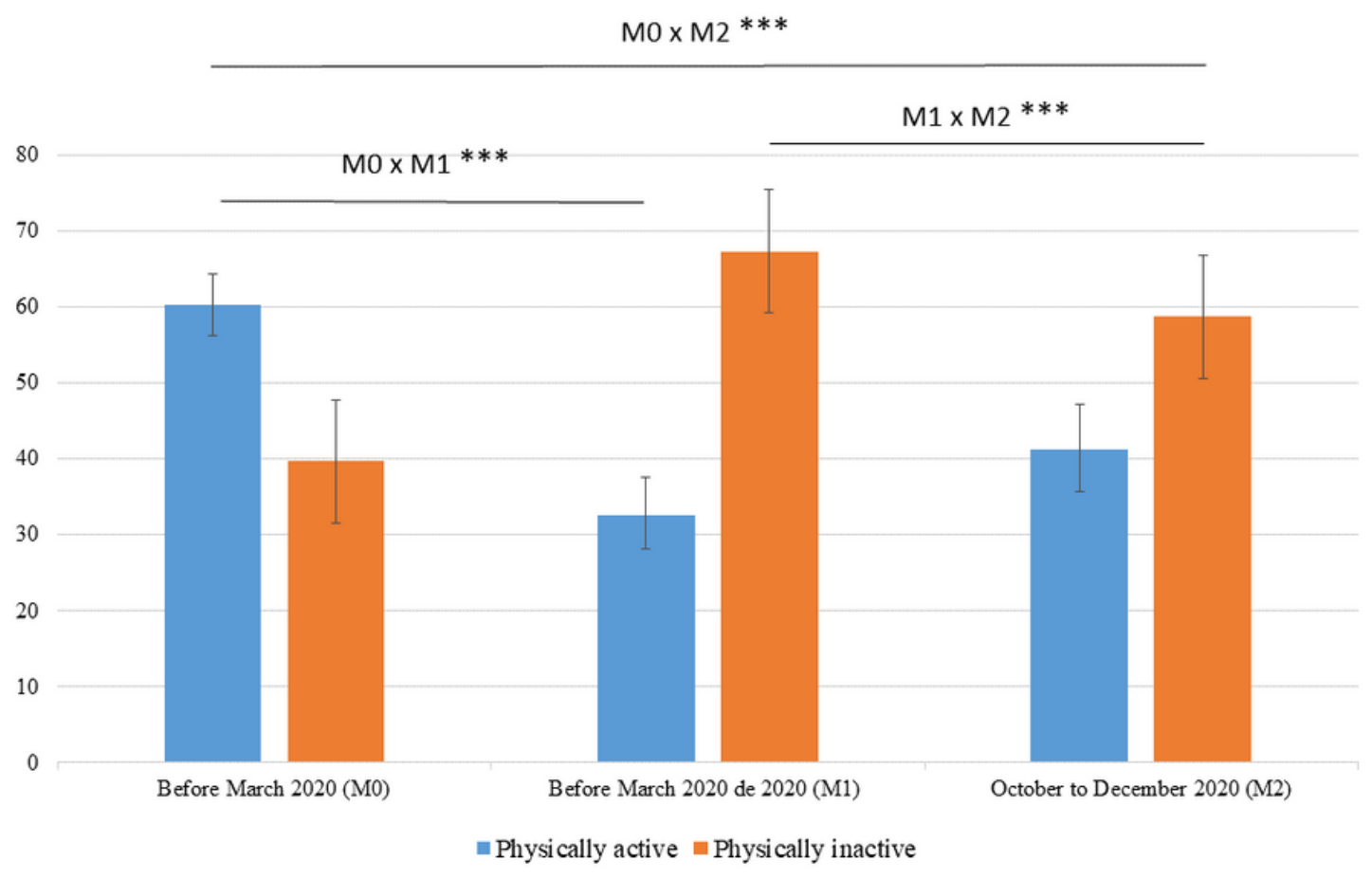

\section{Figure 1}

Prevalence of physical inactivity at moments M0 (before the pandemic), M1 (March to July 2020) and M2 (October to December 2020). (COVID-Inconfidentes, 2020). ${ }^{*} p<0.05,{ }^{* \star} p<0.01,{ }^{* \star \star} p<0.001$. McNemar's paired test. 